"Mircea cel Batran" Naval Academy Scientific Bulletin, Volume XIX - 2016 - Issue 1

Published by "Mircea cel Batran" Naval Academy Press, Constanta, Romania // The journal is indexed in:

PROQUEST / DOAJ / DRJI / JOURNAL INDEX / I2OR / SCIENCE LIBRARY INDEX / Google Scholar / Crossref /

Academic Keys / ROAD Open Access / OAJI / Academic Resources / Scientific Indexing Services / SCIPIO

\title{
FOCUS ON THE USE OF A MARITIME ENGLISH VISUAL DICTIONARY IN ESP CLASSES
}

\author{
Delia LUNGU ${ }^{1}$ \\ Laura CIZER ${ }^{2}$ \\ ${ }^{1}$ Associate Professor, PhD. Department of Navigation and Maritime and River Transport, Faculty of \\ Navigation and Management, "Mircea cel Batran" Naval Academy, Constanta, Romania \\ ${ }^{2}$ Lecturer, PhD. Department of Electrical Engineering and Naval Electronics, Faculty of Marine Engineering, \\ "Mircea cel Batra"n Naval Academy, Constanta, Romania, lauracizer@yahoo.co.uk
}

\begin{abstract}
Whether in paper or online formats, dictionaries are more than just collections of words, and used properly, they could lead towards the development of learners' autonomy. Once students are taught how to use them effectively, there are hundreds of hours of self-guided study. Dictionaries can constitute an ideal way of enriching students' vocabulary due to the fact that they generate an extremely varied collection of communicative activities, ranging from basic dictionary use to vocabulary and reading skills.

This paper aims to put forward 10 dictionary activities tapping an in-house material (the Online Maritime English Visual Dictionary) as an effective means of boosting students' specialist vocabulary.
\end{abstract}

Keywords: online dictionary, Maritime English, language skills, materials development

\section{INTRODUCTION}

Why using a visual dictionary?

The visual online dictionary is an interactive dictionary with pictures offering an innovative approach for learning the meanings of words. It is an all-in-one reference book in which the picture of a word can be quickly located. It provides an easy and accessible way of learning words, turning it thus into an ideal tool both for teachers and students. Nowadays, dictionary software is also available in PDAs format that can be easily downloaded on computers. Not only on computers can dictionary software be downloaded, but also on mobiles, thus making them accessible anywhere and at any point of an hour.

There are numerous advantages of online dictionaries in general, and of visual dictionaries in particular.

Firstly, they provide complete search regarding definitions, pronunciation, spelling, thesaurus entries and etymology results for any word. The online dictionary can be browsed alphabetically or by the terms related to the word to find the exact meanings and synonyms of the word.

Secondly, they are very user-friendly and convenient to use. By simply entering the word in the search box, one will be automatically directed to the word they are looking up. It is not even necessary to type in the entire word, the very first letters will do the rest and all words beginning with those specific letters will be displayed and thus, the researcher will be able to choose the word they are looking for.
This can be extremely useful especially when one has doubts about the spelling of a certain word. Having a picture displayed next to the searched word will automatically eliminate any ambiguity as to the meaning of that specific word.

\section{METHOD}

The dictionary-based activities devised by the authors of this paper are as follows:

1. Icebreaker (I): What is your priority?

2. Icebreaker (II): Finish off the sentence

3. Developing dictionary skills

4. How do you spell that?

5. Explain that word!

6. Maritime wordsearches

7. Fishing for syllables

8. True or False?

9. Question grid

10. Phonemic contest

The format that each activity follows includes: (1) a brief description that gives a general idea of the activity itself, (2) the level the activity is suitable for, (3) an indication of the time the activity requires, (4) its aim, (5) type of activity (pair or group work, group size), (6) preparation (any material that should be previously prepared), (7) procedure (how to carry out the activity), and (8) remarks (difficulties or other points of general interest that may occasionally occur are pointed out under this heading). The dictionary can be found at this (temporary) address [1].

1. Icebreaker (I): What is your priority? 
"Mircea cel Batran" Naval Academy Scientific Bulletin, Volume XIX - 2016 - Issue 1

Published by "Mircea cel Batran" Naval Academy Press, Constanta, Romania // The journal is indexed in: PROQUEST / DOAJ / DRJI / JOURNAL INDEX / I2OR / SCIENCE LIBRARY INDEX / Google Scholar / Crossref /

Academic Keys / ROAD Open Access / OAJI / Academic Resources / Scientific Indexing Services / SCIPIO

(1) Description: The students decide what is important for them when using dictionaries

(2) Level: intermediate

(3) Time: 10 minutes +

(4) Aim: to raise awareness of students' priorities in using dictionaries; to teach the contents of a dictionary

(5) Type of activity: plenary, in pairs

(6) Preparation: copy of Worksheet 1 for each student

(7) Procedure: The teacher $(T)$ invites the students (Ss) to think about the reasons they use dictionaries. Then, $T$ gets them to compare their answers with their partners. T distributes WS 1 and asks Ss to complete it. After a few minutes, Ss start discussing their choices with their partners. The activity finishes off with a quick feedback conducted by $T$ and a final discussion whether anyone is willing to change their opinions.

(8) Remarks: This activity has been designed in order to find out how students feel about using dictionaries, the problems they face, and it has also been intended as a springboard for discussion.

WS 1

\section{WHAT IS YOUR PRIORITY?}

Rank the following from 1-10 according to their importance when you use a dictionary. (1- the most important and 10 - the least important)

1. Spelling

2. Pronunciation

3. Examples

4. Translations

5. $\overline{\text { Explanations }}$

6. Meaning

7. $\overline{\text { Illustrations }}$

8. Understanding when to use words

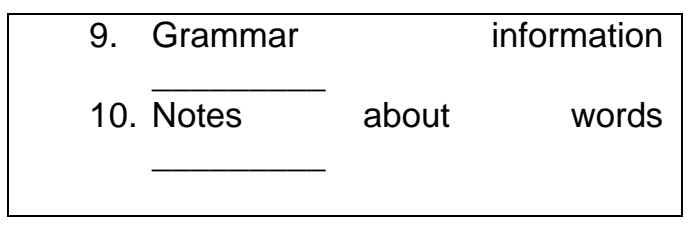

2. Icebreaker (II): Finish off the sentence

(1) Description: Ss will discover what they find most useful in using dictionaries and what they need help with.

(2) Level: elementary and above

(3) Time: 20 minutes

(4) Aim: to assess how Ss feel about using dictionaries; identify their problems and find strategies to overcome them

(5) Type of activity: plenary, in pairs

(6) Preparation: slips of paper with unfinished sentences (WS 2)

(7) Procedure: T hands out WS 2 and tells Ss that they must complete the beginning of the 4 sentences themselves. Ss are given a couple of minutes to complete each sentence, individually. Then, in pairs, they compare and contrast their answers, with a focus on discussing the reasons for their different answers.

(8) Remarks: See previous activity

WS 2

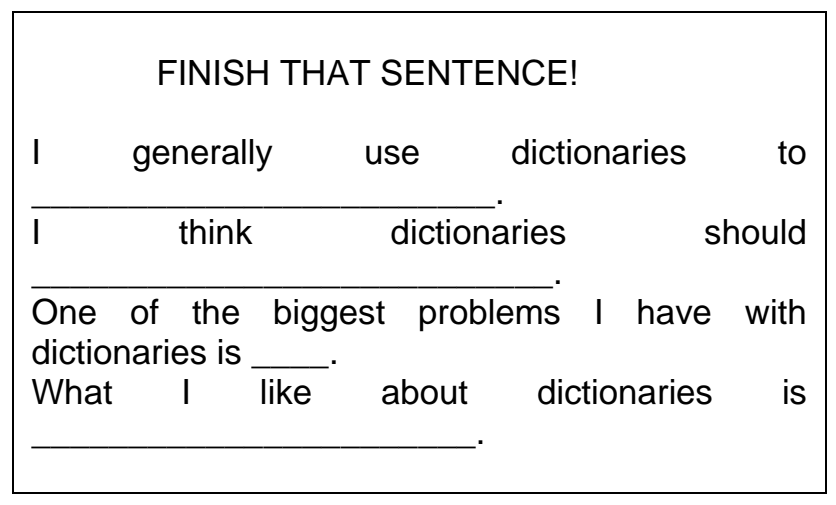

3. Guess that word!

(1) Description: Ss are supposed to guess maritime-related words from their definitions.

(2) Level: elementary and above

(3) Time: 20 minutes

(4) Aim: to use menu definitions to understand meaning of words

(5) Type of activity: small groups 
"Mircea cel Batran" Naval Academy Scientific Bulletin, Volume XIX - 2016 - Issue 1

Published by "Mircea cel Batran" Naval Academy Press, Constanta, Romania // The journal is indexed in: PROQUEST / DOAJ / DRJI / JOURNAL INDEX / I2OR / SCIENCE LIBRARY INDEX / Google Scholar / Crossref /

Academic Keys I ROAD Open Access / OAJI / Academic Resources / Scientific Indexing Services / SCIPIO

(6) Preparation: short definitions taken from the dictionary (WS 3)

(7) Procedure: $T$ divides the class into groups and asks them to examine the short definitions so as to guess which word they are describing. They write down their suggestions, discuss them, and then check in the dictionary

(8) Remarks: This type of activity allows for practically choosing any word in the dictionary, provides the opportunity to group words under a specific topic (such as anchoring, navigational aids, lifesaving or firefighting equipment, etc.), and may well function as a revision activity. This activity can be further developed by asking Ss to look up maritime words in the dictionary, make a list of 4 short definitions in the same way, pass it to their neighbors, and test each other.

WS 3

\begin{tabular}{|c|c|}
\hline $\begin{array}{l}\text { 1. a chain or rope } \\
\text { for mooring a } \\
\text { vessel } \\
\text { 2. the means by } \\
\text { which a ship or } \\
\text { boat is moored } \\
\text { 3. a mooring rope } \\
\text { 4. a mooring line } \\
\text { securing a ship to } \\
\text { that part of a pier } \\
\text { alongside it }\end{array}$ & $\begin{array}{l}\text { 1. a device } \\
\text { attached to a } \\
\text { vessel by a cable } \\
\text { and dropped } \\
\text { overboard so as } \\
\text { to grip the } \\
\text { bottom and } \\
\text { restrict the } \\
\text { vessel's } \\
\text { movement } \\
\text { 2. that portion of } \\
\text { a harbor or area } \\
\text { outside a harbor } \\
\text { suitable for } \\
\text { anchoring or in } \\
\text { which ships are } \\
\text { permitted to } \\
\text { anchor } \\
\text { 3. to release (a } \\
\text { rope) gradually } \\
\text { 4. chain attached } \\
\text { to the anchor }\end{array}$ \\
\hline $\begin{array}{l}\text { 1. a very strong } \\
\text { rope made of } \\
\text { strands of metal } \\
\text { wire used for } \\
\text { towing } \\
2 \text { a specially } \\
\text { designed vessel } \\
\text { which tows other } \\
\text { vessels } \\
\text { 3. a system of } \\
\text { maritime signals }\end{array}$ & $\begin{array}{l}\text { 1. a boat, } \\
\text { propelled by oars } \\
\text { or a motor, used } \\
\text { for rescuing } \\
\text { people at sea, } \\
\text { escaping from a } \\
\text { sinking ship, etc. } \\
\text { 2. any of various } \\
\text { kinds of buoyant } \\
\text { device for } \\
\text { keeping people }\end{array}$ \\
\hline
\end{tabular}

Answers: Mooring: fast, mooring lines/ropes, headline, breast line; Anchoring: anchor, anchorage, to pay out, anchor chain; Towing: towline, tug, International Code of Signals, hawser; Lifesaving appliances: lifeboat, lifebuoy, EPIRB, PFD

4. How do you spell that?

(1) Description: Ss will deal with the most commonly misspelt maritime words that they need to know how to spell for future work.

(2) Level: elementary and above

(3) Time: 20 minutes

(4) Aim: to sensitize students to spelling problems

(5) Type of activity: individual work, then pairs

(6) Preparation: a list of words (WS 4), a two-column table (WS 5)

(7) Procedure: T hands out WS 5 and tells Ss that s/he is going to dictate some words. They must write each word in one of the columns depending on whether they are sure how to spell it or not. If Ss do not know how to spell a particular word, they will simply put it in the "Not sure" column. $\mathrm{T}$ dictates the list of words, giving each a number (Ss should write the number as well). Then, they compare their answers in pairs, and finally check them in the dictionary at https://ebooks.anmb.ro/dictionar.

(8) Remarks: The competitive element could be introduced by giving two points for each correct answer (in the "sure" column).

WS 4

\section{LIST OF WORDS}


"Mircea cel Batran" Naval Academy Scientific Bulletin, Volume XIX - 2016 - Issue 1

Published by "Mircea cel Batran" Naval Academy Press, Constanta, Romania // The journal is indexed in: PROQUEST / DOAJ / DRJI / JOURNAL INDEX / I2OR / SCIENCE LIBRARY INDEX / Google Scholar / Crossref /

Academic Keys I ROAD Open Access / OAJI / Academic Resources / Scientific Indexing Services / SCIPIO

\begin{tabular}{|c|}
\hline $\begin{array}{l}\text { accommodation crew forecastle moor row } \\
\text { athwartships } \\
\text { splice customs forward muster } \\
\text { ore tug berth ensign gauge pier watertight } \\
\text { binoculars } \\
\text { wharf bPIRB gunwale quarter } \\
\text { quay whistle buoy flood headquarters } \\
\text { roadstead }\end{array}$ \\
\hline
\end{tabular}

WS 5

Write the words you hear in one of the two columns below according to how sure you are of their spelling.

\begin{tabular}{|l|l|}
\hline SURE & NOT SURE \\
\hline 1. & 1. \\
2. & 2. \\
. &. \\
. &. \\
. &. \\
\hline
\end{tabular}

5. Explain that word!

(1) Description:

(2) Level: intermediate and above

(3) Time: 20 - 30 minutes

(4) Aim: to develop students' skill in using definitions

(5) Type of activity: small groups

(6) Preparation: online dictionary

(7) Procedure: $\mathrm{T}$ divides the class into small groups, directs each group to the online dictionary and invites them to choose several words. One member of each group explains one word but without saying the actual word. The other group must try to remember and call out the word. Once the word has been guessed, another member of the group gets to use the dictionary and explains another word. They continue until everyone has had a go.

(8) Remarks: This is a variation of activity no.3 (Guess that word!).

6. Maritime wordsearches

(1) Description: Ss will complete and create wordsearches.
(2) Level: elementary and above

(3) Time: 25-35 minutes

(4) Aim: to practice word recognition skills and spelling

(5) Type of activity: pairs

(6) Preparation: a sample wordsearch (WS 6), a blank grid with 100 squares (10X10) for every two students (WS 7); dictionary

(7) Procedure: Ss are presented with a wordsearch (WS 6) which contains a number of hidden words that begin with the same letter and come from the same page of the dictionary; they could be written horizontally, vertically, or diagonally, and forwards or backwards. They are told the first word on the page and asked to report how many words they can find in two minutes. Then, Ss are put in pairs, each pair is given a blank wordsearch grid (WS 7), asked to find a page of their dictionary (all should choose a different one) and keep it a secret. The pairs look through the words together for a couple of minutes, choose ten words from their page and write them in their blank grid horizontally, vertically, or diagonally, forwards or backwards, as in the previous example. They fill the rest of the grid with random letters to "hide" these words in the wordsearch. Pairs swap completed wordsearches and have five minutes (or more depending on students' level) to find as many of the ten hidden words as possible.

(8) Remarks: The word search has been devised by using Puzzlemaker [2] which is a puzzle generation tool that helps create and print customized word search from your own word lists. The sample word search is based on the following ten words: abaft, abeam, aboard, abreast, admiral, adrift, afloat, aground, aloft, anchor, which have been extracted from letter $A$ of the maritime English visual dictionary.

WS 6

\begin{tabular}{|l|l|l|l|l|l|l|l|l|l|}
\hline T & B & W & S & N & S & U & L & E & D \\
\hline M & S & J & D & R & W & I & Q & T & N \\
\hline
\end{tabular}


"Mircea cel Batran" Naval Academy Scientific Bulletin, Volume XIX - 2016 - Issue 1 Published by "Mircea cel Batran" Naval Academy Press, Constanta, Romania // The journal is indexed in: PROQUEST / DOAJ / DRJI / JOURNAL INDEX / I2OR / SCIENCE LIBRARY INDEX / Google Scholar / Crossref / Academic Keys / ROAD Open Access / OAJI / Academic Resources / Scientific Indexing Services / SCIPIO

\begin{tabular}{|c|c|c|c|c|c|c|c|c|c|}
\hline A & L & A & R & I & M & D & A & A & U \\
\hline E & P & C & E & T & D & O & Y & L & O \\
\hline B & T & X & P & R & L & D & A & O & R \\
\hline A & Q & E & H & F & B & R & N & F & G \\
\hline H & D & R & A & O & B & A & C & T & A \\
\hline A & D & R & I & F & T & T & H & H & U \\
\hline B & I & A & B & A & F & T & O & A & I \\
\hline M & D & K & W & W & F & Z & R & E & A \\
\hline
\end{tabular}

Answer key: $A B A F T(3,9, E) ; A B E A M$ $(1, \quad 6, \quad N) ; \quad A B O A R D ; \quad(7, \quad 7, W)$ ABREAST (7,7,NW); ADMIRAL $(8,3, W) ; \quad A D R I F T(1,8, E) ; \quad A F L O A T$ $(4,7, N E) ; \quad$ AGROUND $(10,7, N)$; $\operatorname{ALOFT}(9,3, S) ; \operatorname{ANCHOR}(8,5, S)$

WS 7

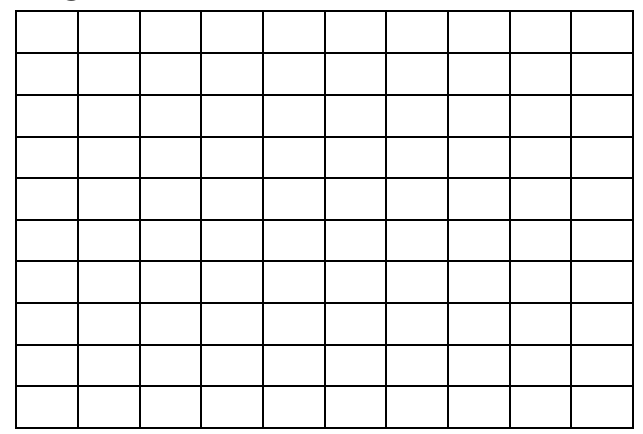

7. Fishing for syllables

(1) Description: Ss will combine syllables to find maritime-related words within a time limit.

(2) Level: false beginners and above

(3) Time: 20 - 30 minutes

(4) Aim: to understand how words are formed in terms of syllables; to learn how to pronounce words, to practice pronunciation

(5) Type of activity: groups (of four preferably)

(6) Preparation: online dictionary, copies of WS 8 (on to thin cardboard and cut out so that each syllable is on a different piece of card; cards are put into sets, then shuffled so that they are out of order)

(7) Procedure: T puts Ss into groups of four and gives each group a set of cards. Ss must try to recombine the syllables to make as many words as possible in five minutes and list their words in alphabetical order. Each group is put together with another group with a view to comparing their words and discussing the meanings of any new words.

(8) Remarks: The example below is based on letter $A$ of the dictionary and contains 16 words, but other letters can be successfully used.

WS 8

\begin{tabular}{|l|l|l|l|l|l|}
\hline AN & CHOR & AC & COM & MO & DA \\
\hline TION & LAD & DER & A & BOARD & AD \\
\hline MI & RAL & AL & BA & TROSS & AMID \\
\hline SHIPS & AN & CHOR & AGE & WIND & LASS \\
\hline A & THWART & SHIPS & AU & TO & MA \\
\hline TIC & AWN & ING & AZI & MUTH & AN \\
\hline TENNA & ALONG & SIDE & AN & EMOM & ETER \\
\hline
\end{tabular}

8. True or False?

(1) Description: Ss decide whether statements are true or false in terms of meaning, spelling and pronunciation, and produce other statements in a similar way.

(2) Level: elementary and above

(3) Time: 30 - 40minutes

(4) Aim: to practice general dictionary skills, to encourage close reading of dictionary entries

(5) Type of activity: pairs

(6) Preparation: copies of WS 9 for everyone, online dictionary

(7) Procedure: Ss are given the worksheet and asked to complete it in pairs, using the dictionary for reference. T checks the answers (see Answer Key), then tells the pairs to make a similar worksheet with 6 questions using the entries of one dictionary letter; questions should include spelling, meaning, pronunciation. T monitors as the pairs produce their worksheets and helps with any problems. The pairs swap finished worksheets with their neighbors and answer them.

(8) Remarks: This can be assigned as homework.
WS 9

\section{THREE TRUE, THREE FALSE}

Three of these statements are TRUE, 
"Mircea cel Batran" Naval Academy Scientific Bulletin, Volume XIX - 2016 - Issue 1 Published by "Mircea cel Batran" Naval Academy Press, Constanta, Romania // The journal is indexed in: PROQUEST / DOAJ / DRJI / JOURNAL INDEX / I2OR / SCIENCE LIBRARY INDEX / Google Scholar / Crossref / Academic Keys / ROAD Open Access / OAJI / Academic Resources / Scientific Indexing Services / SCIPIO

and three are FALSE. Which is which?

1. Abaft and astern mean the same.

2. Adrift has one syllable.

3. The correct spelling of a cabin or other facilities onboard is accommodation.

4. Anchor is pronounced ['æךkə].

5. An antenna is used for measuring the speed of wind.

6. The word that defines the length from one side of the ship to the other is spelt athwartships.

Answer Key: True - 1, 4, 6; False - 2, 3, 5

9. Question grid

(1) Description:

(2) Level: elementary and above

(3) Time: 30 minutes

(4) Aim: to provide skills practice, to revise question formation, to develop vocabulary

(5) Type of activity: groups

(6) Preparation: online dictionary, WS 10

(7) Procedure: $\mathrm{T}$ demonstrates the task through WS 10, then divides the class into groups of three or four, asks each group to open up a dictionary page at their choice and to study it for several minutes. T also asks them to draw a noughts and crosses grid (3X3 squares) on a separate piece of paper and put nine different words from the page into the boxes, one into each box. Next step is to swap completed grids, use their dictionaries to compose their questions or prompts for which the nine words are the answers. They can include pictures, opposites, pronunciations, or translations. Make sure the questions are not in the same order as the nine words in the grid. The groups pass the grids and questions to another group, who match the questions and answers without using dictionaries. They should discuss the questions and work by consensus, not just guesswork. Dictionaries should be used in order to check the answers.

(8) Remarks: This may very well function as a revision activity (if words come from a recent class), or to introduce new vocabulary items.

WS 10

\begin{tabular}{|l|l|l|}
\hline anchor & aloft & anchor chain \\
\hline $\begin{array}{l}\text { a } \\
\text { horizontal } \\
\text { winch for } \\
\text { raising the } \\
\text { anchor }-\theta \text { 't, JIps] }\end{array}$ & behind a ship \\
$\begin{array}{l}\text { anchor } \\
\text { windlass }\end{array}$ & & \\
\hline $\begin{array}{l}\text { at } \\
\text { sea/aboard }\end{array}$ & alarm bell & $\begin{array}{l}\text { geamandură } \\
\text { de ancoră }\end{array}$ \\
\hline
\end{tabular}

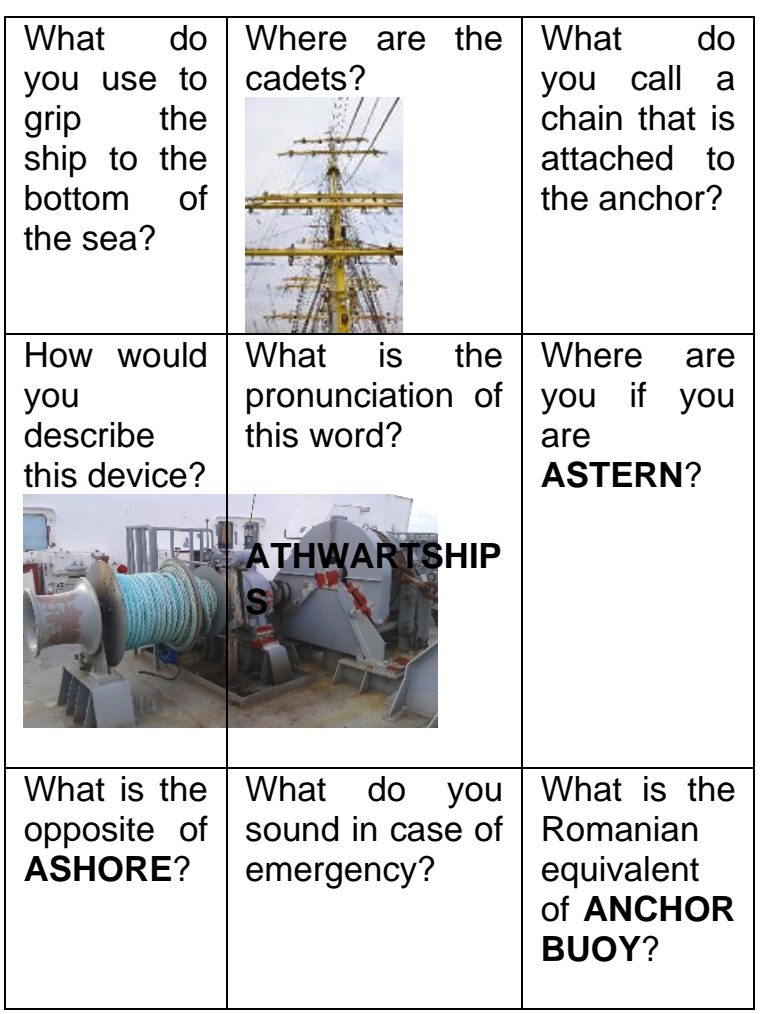

10. Phonemic Contest

(1) Description: Ss will be engaged in a sound recognition of words that will be dictated to them.

(2) Level: elementary and above

(3) Time: 20 minutes + 
"Mircea cel Batran" Naval Academy Scientific Bulletin, Volume XIX - 2016 - Issue 1

Published by "Mircea cel Batran" Naval Academy Press, Constanta, Romania // The journal is indexed in: PROQUEST / DOAJ / DRJI / JOURNAL INDEX / I2OR / SCIENCE LIBRARY INDEX / Google Scholar / Crossref /

Academic Keys I ROAD Open Access / OAJI / Academic Resources / Scientific Indexing Services / SCIPIO

(4) Aim: to develop awareness of phonemic symbols and practice using them

(5) Type of activity: plenary

(6) Preparation: list of words - WS 11 (teacher's use), chart - WS 12

(7) Procedure: Ss receive the $3 \times 3$ grid and are explained that $T$ is going to read out some words. They have to listen out for their sounds and try to complete their grids. Every time they hear a word with one of their sounds in, they write it in the respective square. Then, $T$ starts dictating the words, Ss fill in their squares and the winner is the first to complete the grid.

(8) Remarks: This activity is mostly suited for practicing sounds Ss have problems producing and differentiating. It can also be done in pairs.

WS 11

abeam, admiral, afloat, aground, alongside, athwartships, azimuth, berth, boatswain, breeches buoy, bucket, bulbous bow, bulkhead, bulwark, buoy, chain, etc.

WS 12

\begin{tabular}{|l|l|l|}
\hline$æ$ & ov & I \\
\hline o: & $\wedge$ & i: \\
\hline t & aI & $\theta$ \\
\hline
\end{tabular}

\section{CONCLUSIONS}

Diving into dictionaries in general and into the Maritime English Visual Dictionary in particular offers multiple avenues for interesting activities to hold students' attention and boost their specialist vocabulary in attractive and useful ways.

\section{BIBLIOGRAPHY}

[1] http://ebooks.anmb.ro/dictionar

[2] http://www.discoveryeducation.com/free-puzzlemaker/

[3] Wright, Joe (2001) - Dictionaries. Oxford University Press, Hong Kong 